\title{
Poly [ADP-Ribose] Polymerase 2
}

National Cancer Institute

\section{Source}

National Cancer Institute. Poly [ADP-Ribose] Polymerase 2. NCI Thesaurus. Code

C104720.

Poly [ADP-ribose] polymerase 2 ( $583 \mathrm{aa}, \sim 66 \mathrm{kDa}$ ) is encoded by the human PARP2 gene.

This protein is involved in the initiation of DNA repair. 